\title{
Tristan Murail: a Desforra do Ouvido?
}

\section{Bruno Prunès}

A década de 80 conheceu a emergência de vários movimentos musicais que se colocaram em radical oposição ao serialismo dos últimos trinta anos. Um desses movimentos se distingue dos outros por uma atenção constante ao som, explorando seu espaço interior, cultivando o infracromatismo: ele se chama música espectral.

A maioria dos compositores que confessadamente se inserem nele cita como avós e bisavós: Debussy, Varese, Messiaen, Scelsi e Ligeti. Um pioneiro é Horatiu Radulescu, romeno, residente desde 1971 na França. Alguns outros romenos foram um núcleo importante de músicos ditos "espectrais" - juntamente com uma jovem escola finlandesa. Entretanto, muitos desses compositores com freqüencia trabalham - ou mesmo vivem - na França. Um meio francês de músicos espectrais muito ativos desenvolveu-se: Grisey, Hivrel, Dalbavie, Diorville, Busch, Malherbe, Dufourt, Levinas.

A música espectral leva em conta, antes de tudo, o som e seu halo de ressonâncias harmônicas, seu volume e profundidade, sua projeção espacial. Pode-se dizer que ela é feita antes de sons do que de notas. Neste sentido, não é falso inserila na continuidade de uma tradição francesa: Berlioz, Debussy, Varese - compositores que possuíam uma particular sensibilidade ao timbre.

Com o emprego dos microintervalos, os espectrais aventuram-se no infracromatismo, saem do espaço temperado e a barreira fatídica do $13^{\circ}$ som é ultrapassada. Uma nova harmonia nasce com quartos de tons que são necessários, que estão situados no seu preciso lugar e que soam bem.

O tempo não é o dos acontecimentos, dos episódios, mas é preciso não nos enganarmos: muitas coisas se passam nesta música. Basta escutar, segundo a palavra de ordem de Claude Debussy. E, ao ouvir, a orquestra parece ser uma imensa massa sonora que se movimenta e se transforma. O som musical é em realidade o som "natural" tomado como modelo. É analisado, e tiram-se as conseqüências para a escrita num nível harmônico e num nível formal. Os instrumentos modernos de análise, fornecidos pela eletrônica clássica e agora pelo computador, tornam-se assistentes do compositor, oferecendo-lhe os meios de compreender a estrutura íntima dos sons. "Espectro" é seu desmembramento em componentes elementares, é a tomada em consideraçāo de seu aspecto dinâmico - isto é, o modo como variam no tempo - e de seu aspecto transitório - isto é, o modo como nascem e desaparecem. O objetivo das técnicas espectrais é, após esse tipo de análise, criar um som global por meio de processos chamados de "síntese instrumental". Estes consideram os instrumentos de música como elementos, ou componentes elementares, de um som global mais geral que será o som da orquestra. O compositor transforma-se numa espécie de escultor: ele cava a matéria sonora, revela uma forma escondida, no oposto de um pedreiro que utiliza tijolos para construir. Ele faz explodir o som c o examina de modo microscópico. O timbre e a harmonia são considerados como dois aspectos da mesma coisa: não se trata mais de dois parâmetros diferentes: trata-se re- 
almente da mesma entidade de base que será percebida, segundo o contexto, como harmonia ou como timbre. $\mathrm{O}$ "conteúdo" e a forma da obra se resumem no fenômeno sonoro. Ali, os mais sutis e ínfimos movimentos de timbres fazem parte, de um modo fundamental, da forma musical. A obra torna-se o testemunho do respeito diante do som escolhido, do seu devir, da sua duração.

Um caso exemplar é o de Tristan Murail. Nascido no Havre em 1947, ele buscou, desde seus tempos de estudante, escapar da camisa-de-força serial, sem cair num qualquer estéril neoclassicismo. Sua formação de organista lhe deu grande intimidade com os sons que podem durar muito tempo. Ele confessa ter herdado do livro de órgão de Grigny uma sensibilidade para a cor, pois a estrutura dessa música é em grande parte baseada no timbre, e a forma em grande parte derivada dos registros, minuciosamente assinalados nas partituras.

Em seguida, Murail empreeendeu o estudo das ondas Martenot com Jeanne Loriod e Maurice Martenot. Aliás, ele é o ondista numa recente gravação da Turangalila Symphonie de Olivier Messiaen dirigida pelo maestro britânico Simon Rattle. É justamente a nomeação de Messiaen para a classe de composição no Conservatório de Paris que leva Murail a se inscrever áli em 1967. Ele concluirá seus estudos com o primeiro prêmio em 1971, e partirá para a Villa Medicis, a Academia da França, em Roma.

Messiaen, em quem Murail encontrou um Mestre num sentido quase oriental do termo, influenciou seu jovem aluno através de uma concepção do tempo muito particular e pelos célebres cursos de 1969, quando desenvolveu a análise da partitura Lontano, de Ligeti. Stimmung, de Stockhausen, peça vocal para seis cantores que repousa sobre um único acorde - em realidade um fragmento de espectro harmônico - e o pensamento de Xenakis, que concebia a música como uma arquitetura do tempo, foram pontos de referência essenciais na formação do estudante Murail.

Durante sua estada em Roma, foi apresentado a G.Scelsi, e descobriu nele um pai espiritual. Scelsi trabalhava havia mais de vinte anos sobre o "som único" e foi um dos primeiríssimos a contrariar o primado de três séculos do meio tom igual.

Voltando à França, Murail funda o conjunto Itinéraire, com instrumentistas e compositores que conhecia dos cursos de Messiaen, como Roger Tessier. Em 1975, deu a primeira apresentação mundial de Mémoire/Érosion, para solo e nove instrumentos. Como Ligeti nos anos 60 , cuja escrita instrumental foi fecundada pela experiência eletroacústica, Murail buscou processos de "reinjeções", com vários gravadores que se remetem mutuamente sons. Esse emprego de processos eletrônicos conduziu à idéia de processos formais que substituem a noção de desenvolvimento na escrita musical. Um som novo, diferente, como o que Debussy obtivera com o Prélude à l' après-midi d'un faune, ou Messiaen com suas Petites Liturgies, apareceu então. Longe da ausência de perspectiva musical e de energia sonora que caracteriza freqüentemente a música serial, Murail trabalha particularmente a textura do som e os fenômenos de ressonância, enfï reabilitados. Pois o princípio da série, como Messiaen já havia demonstrado, abolia ressonância e "cor" harmônica.

Um recente disco laser, editado pela casa A.D.D.A., reúne duas obras para orquestra - Gondroana e Time again -, além de uma obra para fita magnética e dezessete instrumentos: Désintégrations. O conjunto caracteriza bastante bem a obra de Murail.

Gondroana foi citada por Messiaen como uma das mais belas obras de nosso 
tempo. O título se refere a um hipotético continente da época primária. Nela, o modelo é o som, concreto, de um sino: Resultam sonoridades ricamente harmônicas, que se mostram em franca reação a todas as técnicas de cálculos e combinatorias praticadas em numerosas obras dos anos 60 . As notas/som são escolhidas porque "soam bem", e não em virtude de uma qualquer regra ou axioma. A individualidade dos instrumentos se perde completamente ou quase, em benefício de um som sintético da orquestra, cujo princípio unificador é o sino.

Desintegrações é uma obra mista, que mergulha no mundo do infinitamente pequeno. Trata-se de uma encomenda do IRCAM, a fita magnética foi sintetizada sobre a $4 \mathrm{X}$, e o título se refere à desintegração de timbres instrumentais. A obra foi criada num programa que continha também Desertos de Varese, e ela permite perceber o caminho percorrido na elaboração de obras mistas. A "forma" da obra não ocorre através do corte em secções: ela reside num modo de conduzir as mudanças das informaçōes sonoras.

É bem evidente que deste ponto de vista, a Sétima Sinfonia de Mahler, a última de Sibelius, sem falar do próprio Varese, são já caminhos abertos para músicas em que a forma emerge naturalmente do fluxo sonoro. Em Desintegraçóes, os limites precisos entre o material e a forma se apagam; esta não é mais "aplicada" sobre aquele, mas ela decorre dele. O final da peça é um grande momento de poesia lunar, e mostra que para Murail o universo do som é uno. Qual seja a fonte de excitação sonora, eletrônica ou acústica, o que conta é a materialidade do som produzido.

Time again prova que um pensamento especulativo não está excluído do universo "espectral", mas ainda uma vez, e com maior sucesso, o projeto técnico, de escrita, corresponde perfeitamente a um projeto expressivo. Murail compõe com a consciência da força física, cósmica do som. Nisto, ele faz pensar nos músicos das ragas da Índia, ou do Gagaku japonês. Contudo, não há nada de oriental em sua obra. O que existe são sutis transformações de um som em um outro som, de um conjunto de sons num outro conjunto. $O$ desenvolvimento musical, que não é mais o desenvolvimento de uma célula melodica ou rítmica, como ainda em numerosas obras contemporâneas, se faz de um modo quase biológico. Talvez houvesse em todos esses processos técnicos um risco de previsibilidade excessiva. Mas Murail sabe admiravelmente introduzir surpresas, premonições, retornos, guardando sempre o efeito de continuidade. Time again é a melhor obra de Murail até hoje, e permite augurar um excelente futuro. ${ }^{1}$

\section{Nota}

1. Sobre Murail, cf. revista Entretiens, n. 8 (42, rue Montmorency, 75003, Paris).

Bruno Prunès é musicólogo autodidata, residente em Toulouse (França). 